\title{
Catastrophic out-of-pocket payments for households of people with severe mental disorder: a comparative study in rural Ethiopia
}

Yohannes Hailemichael ${ }^{1 *}$, Damen Hailemariam ${ }^{1}$, Kebede Tirfessa ${ }^{2}$, Sumaiyah Docrat ${ }^{4}$, Atalay Alem², Girmay Medhin ${ }^{5}$, Crick Lund ${ }^{3,4}$, Dan Chisholm ${ }^{6}$, Abebaw Fekadu ${ }^{2,7}$ and Charlotte Hanlon²,3

\begin{abstract}
Background: There are limited data on healthcare spending by households containing a person with severe mental disorder (SMD) in low- and middle-income countries (LMIC). This study aimed to estimate the incidence and intensity of catastrophic out-of-pocket (OOP) payments and coping strategies implemented by households with and without a person with SMD in a rural district of Ethiopia.

Methods: A comparative cross-sectional community household survey was carried out from January to November 2015 as part of the Emerald programme (emerging mental health systems in low- and middle-income countries). A sample of 290 households including a person with SMD and 289 comparison households without a person with SMD participated in the study. An adapted and abbreviated version of the World Health Organization SAGE (Study on global Ageing and adult health) survey instrument was used. Households were considered to have incurred catastrophic health expenditure if their annual OOP health expenditures exceeded $40 \%$ of their annual non-food expenditure. Multiple logistic regression was used to explore factors associated with catastrophic expenditure and types of coping strategies employed.
\end{abstract}

Results: The incidence of catastrophic OOP payments in the preceding 12 months was $32.2 \%$ for households of a person with SMD and $18.2 \%$ for comparison households $(p=0.006)$. In households containing a person with SMD, there was a significant increase in the odds of hardship financial coping strategies $(p<0.001)$ : reducing medical visits, cutting down food consumption, and withdrawing children from school. Households of a person with SMD were also less satisfied with their financial status and perceived their household income to be insufficient to meet their livelihood needs $(p<0.001)$.

Conclusions: Catastrophic OOP health expenditures in households of a person with SMD are high and associated with hardship financial coping strategies which may lead to poorer health outcomes, entrenchment of poverty and intergenerational disadvantage. Policy interventions aimed at financial risk pooling mechanisms are crucial to reduce the intensity and impact of OOP payments among vulnerable households living with SMD and support the goal of universal health coverage.

Keywords: Catastrophic health expenditure, Severe mental disorders, Low- and middle-income, Ethiopia, Universal health coverage

\footnotetext{
*Correspondence: yohannes.h.michael@gmail.com

${ }^{1}$ Department of Reproductive Health and Health Services Management,

School of Public Health, College of Health Sciences, Addis Ababa

University, Addis Ababa, Ethiopia

Full list of author information is available at the end of the article
}

(c) The Author(s) 2019. This article is distributed under the terms of the Creative Commons Attribution 4.0 International License (http://creativecommons.org/licenses/by/4.0/), which permits unrestricted use, distribution, and reproduction in any medium, provided you give appropriate credit to the original author(s) and the source, provide a link to the Creative Commons license, and indicate if changes were made. The Creative Commons Public Domain Dedication waiver (http://creativecommons.org/ publicdomain/zero/1.0/) applies to the data made available in this article, unless otherwise stated. 


\section{Introduction}

In a recent global monitoring report by the World Health Organization (WHO) and the World Bank, the incidence of catastrophic health expenditure was shown to have increased globally [1]. Indeed, each year, 100 million people face poverty and another 800 million people suffer due to catastrophic out-of-pocket (OOP) health expenditures [1]. Out-of-pocket payments make up a significant proportion of the total expenditure on mental health care in most low-income countries [2]. In $43 \%$ of countries in the African region, OOP spending is the main source of financing for mental health services [3].

In 2013/14, total health expenditure was approximately $4.7 \%$ of Ethiopian gross domestic product (GDP), with per capita health expenditure amounting to US\$28.65 [4]. Household out-of-pocket expenditure represents the largest financing source for health care, accounting for about 33\% of total health expenditure [4]. Although a fee waiver program was introduced as a measure to protect the poor from the negative effects of out-of-pocket payments in Ethiopia, the coverage remains low in many regions [5]. Hence, chronic illnesses with ongoing need for care, as is seen with severe mental disorders (SMD) such as schizophrenia and bipolar disorder, exert a heavy economic burden on vulnerable households in accessing mental healthcare [6]. Evidence indicates that the extent of out-of-pocket payments for mental health problems varies from country to country and according to the methodology used [7-9]. In an Indian study, the percentage of women with severe depression who had experienced catastrophic expenditure was $14.6 \%$, compared to $4.9 \%$ for the non-cases [7]. Similarly, in a study conducted in Bangladesh, $15.1 \%$ of households with a person with mental illness encountered increased household expenditure that resulted in distress financing [8].

Out-of-pocket health care spending imposes a substantial financial burden on households in many countries and leads the household to sacrifice consumption of other items, to incur debts, or to sell productive resources $[10,11]$. Furthermore, health care expenditures have been reported as one of the major pathways into poverty and an important reason why many households remain poor [12-15].

Although studies have reported the impact of out-ofpocket expenditure on households; the investigation of household costs of disease is incomplete if coping strategies employed by households are ignored [16, 17]. Evidence suggests that in most African countries, the health financing system is too weak to protect households from health shocks (illness). Hence, using coping strategies to finance health care is common [18]. These strategies include informal transfers (in cash and in-kind) from relatives and friends [19], selling assets [20] or obtaining loans [14, 21], withdrawing children from school [20,22] and taking on extra work [23]. Evidence from middleincome Asian countries, including China [24], Vietnam [25, 26], and Thailand [27], indicates that illness and associated medical expenditures have a significant negative impact on household basic consumption. In the Ethiopian context, Asfaw and Braun [28] and Dercon et al. [29] show that when the head of the household is the person who is unhealthy, non-medical consumption declines sharply, with reductions ranging from 15 to $35 \%$.

The study reported in this paper is part of the crosscountry Emerald programme (emerging mental health systems in low- and middle-income countries) which sought to provide rigorous, population-based evidence about the adequacy and fairness of mental healthcare financing [30].

In this study, we investigated health expenditure and financial coping strategies in relation to SMD in rural Ethiopia. We hypothesized that the incidence and intensity of catastrophic health expenditure and associated coping strategies would be significantly higher in households including a person with SMD compared to households with no affected family member. We also explored the factors associated with catastrophic health expenditure and coping strategies.

\section{Methods}

\section{Study design, setting, and participants}

A comparative cross-sectional household survey was carried out in Sodo district, in southern Ethiopia. Administratively, Sodo is structured into 58 sub-districts (kebeles) with a total population of 161,952 , of which $90 \%$ resides in rural areas [31]. At the time of this study, primary health care was provided in eight health centers and in 58 health posts. There are also a number of private clinics and drug vendors throughout the district [32]. Sodo district was the site for a model of primary care-based mental healthcare, through the PRogramme for Improving Mental health carE (PRIME) [33]. The Emerald programme was linked to PRIME, with the overall aim of investigating the health system interventions required to support integrated primary mental health care. The current study was conducted as part of Emerald at the baseline of PRIME, prior to implementation of mental healthcare. At that time, there was no mental health service available in the district. Psychiatric nurse-led outpatient care was available $30-50 \mathrm{~km}$ away and the closest in-patient mental health care was available in the capital city, Addis Ababa (100 km away). However, the SAGE questionnaire also included OOP costs for non-specialist health care, conceptualized broadly to also include care from religious and traditional healers. 
Community-based identification of people with possible SMD $(\mathrm{n}=467)$ was conducted by community-based health extension workers and community leaders who had received half a day of training on common presentations of SMD for the setting [33]. This approach was used previously in the nearest district and found to be effective [34]. Referred cases were screened by a primary care worker based at the local health center. The primary care workers (nurses, health officers and midwives) had been trained using the World Health Organization mental health Gap Action Programme (mhGAP) [35]. The primary care workers followed the mhGAP intervention guide to make diagnoses of psychosis or bipolar disorder $(n=294)$. A confirmatory clinical diagnosis of SMD (any psychotic disorder or bipolar disorder) $(\mathrm{n}=300)$ was then made by psychiatric nurses trained to administer the operational criteria for research (OPCRIT) semistructured clinical interview [36].

For this sample, the comparison group $(n=289)$ of households of persons without SMD who fulfilled the matching criteria was randomly selected from a sampling frame based on a household census of the district which was conducted by PRIME [37]. Households of a person with SMD were matched to comparison households without a person with SMD on the basis of age of the household head, gender, gott (lowest residential administrative area) and household size. The eligibility criteria were: age 18 years and above, planned to reside in the area for the next 12 months (to participate in the longitudinal study) and able to comprehend the interview. Recruitment took place from January to November 2015.

\section{Data collection, definitions, and measurements}

Outcome data were collected using an adapted and abbreviated version of the World Health Organization SAGE (Study on global Ageing and adult health) survey instrument [38]. The instrument was used to collect information on: (i) household characteristics (sex, age, schooling, marital status, residence); (ii) housing characteristics (type, building materials, water, sanitation and ownership); (iii) household consumption expenditures (collected item by item); and (v) household and family support networks and transfers, including financial/ non-financial help from family and friends. Different reference periods were used for each type of expenditure: 7 day, 30 day and 12 month recall periods prior to the date of interview. The household questionnaire was administered to the household head by trained and experienced data collectors. In the absence of the household head the most knowledgeable member of the household about the household consumption was interviewed.

Out-of-pocket payment for health care includes all categories of expenditures for consultation, investigations, medication and other procedures or interventions, for all types of healthcare, including biomedical, traditional and religious healing with a 1 month recall period, and the costs of infrequent health care (i.e. hospital admissions) over a 12 month recall period. Household health expenditures were converted and summed to obtain the annual cost and then expressed as a percentage of annual household total consumption expenditure and non-food consumption expenditure at various threshold levels.

The primary outcome (incidence of catastrophic outof-pocket payment for health care) was measured as the percentage of households incurring health payments in excess of a specified threshold in 1 year [39]. The intensity of catastrophic costs measures the extent to which households exceeded the chosen threshold [40]. Overshoot, which equals the difference between the estimated out-of-pocket payment as a share of total consumption expenditure or capacity to pay and the threshold among all individuals; and the mean positive overshoot, which indicates the overshoot among the subgroup of those who exceeded the threshold [40]. However, the threshold levels considered for calculation of catastrophic payments may differ according to country context [11, 41]. Therefore, a sensitivity analysis was performed using various thresholds (i.e. $5 \%, 10 \%, 15 \%, 20 \%, 25 \%$ and $40 \%$ ) of household total consumption expenditure and household capacity to pay. In the literature the threshold of what constitutes catastrophic expenditure is debatable. The most widely accepted method in the literature and recommended by the World Health Organization and $\mathrm{Xu}$ et al. [11] for measuring the incidence of catastrophic payments is capacity to pay [42]. Capacity to pay is defined as payment on non-discretionary or nonsubsistence spending (roughly, non-food expenditure). We estimate health expenditure to be catastrophic when it exceeds $\geq 40 \%$ of non-food expenditure.

The choice of the threshold level is based on the idea that households will be left with a certain balance of their pre-expenditure income or capacity to pay that would allow them to spend on other needs in the household [40, 43].

With regard to coping strategies (the secondary outcome), the survey included questions on the strategies that the household had employed in response to financial distress over the previous year. Such strategies included the following: cost minimization strategies (i.e. withdrawing children from school, reducing food consumption, reducing frequency of medical visits); and cost management strategies (i.e. use of savings, finding extra work, taking out loans from a bank or money lender, drawing up accounts at shops, and asking friends and relatives for help) [10]. 
Functional disability in the previous month for the index patient and for the interviewed household member in the comparison group was assessed using the 36-item World Health Organization Disability Assessment Schedule-II (WHODAS-II), which has been previously validated in a rural Ethiopian setting [44].

\section{Statistical analysis}

The data were double-entered using Epidata 3.1 [45] and cleaned and analyzed using STATA version 13.1 [46]. The two-sample $t$ test, the non-parametric Mann-Whitney test and Chi-square test-for-trend were used to compare means, medians and proportions across households with a person with SMD and households without the disorder. Chi-square test was used to examine bivariate association of mental health status with catastrophic payment at the $5 \%, 10 \%, 15 \%, 20 \%, 25 \%$ and $40 \%$ thresholds. The crude and adjusted association of different factors with catastrophic health payment based on capacity to pay ( $\geq 40 \%$ of household non-food consumption) were estimated with odds ratios, 95\% confidence intervals and p-values, using logistic regression. Households that incurred health payments in the previous year and risk factors were included in the regression model.

Logistic regression models were fitted to examine the independent effect of having a person with SMD in the household on catastrophic expenditure and to explore the factors associated with a greater likelihood of implementing particular coping strategies. The model was run separately for each coping strategy using the same set of independent variables. Odds ratios and 95\% confidence intervals were used as the measure of the effect size.

\section{Results}

A flow diagram of participant recruitment and inclusion in the study is presented in Additional file 1: Figure S1.

\section{Household socio-demographic and economic characteristics}

The study enrolled 290 households including persons with SMD, with a total of 1513 household members, and 289 households of a person without a person with SMD, with a total of 1522 household members. As shown in Table 1, the mean age of the household head was nearly 50 years in both groups. The mean number of adults per household was higher in households of a person with SMD than in comparison households (3.2 vs. 2.9; $\mathrm{p}=0.004$ ). A higher proportion of head of households of a person with SMD were never married $(p=0.007)$. The proportion of households covered by health insurance was lower for households having a member with SMD compared to households without a person with SMD $(1.0 \%$ vs. $2.7 \% ; p=0.262)$. The mean number of children younger than 15 years for households of a person with SMD was considerably lower than for comparison households $(\mathrm{p}=0.004)$. Households of a person with SMD reported higher levels of disability $(\mathrm{p}<0.001)$ and lower median (inter-quartile range; IQR) expenditure on annual food consumption (Birr 6087.8; IQR 3785.5, 9533.3), than households without a person with SMD (Birr 6240.0; IQR $4356.7,10,111.1)$.

\section{Out-of-pocket (OOP) health expenditure}

Of the 290 households with SMD 83.1\% $(n=241)$ and out of 289 households without SMD, 39.7\% $(n=115)$ had accessed and received services in terms of consultations, medications, investigations, traditional healing, hospitalization and other services in the previous 1 month and 12 months preceding the day of the data collection.

OOP payments as a share of total consumption were not significantly higher for households of a person with SMD than in comparison households (6.9\% vs. 5.7\%). The percentages of health payments spent on medication $(74.1 \%$ vs. $71.1 \%)$, investigations $(29.6 \%$ vs. $26.4 \%)$, and consultations $(16.7 \%$ vs. $16.3 \%)$ were non-significantly higher for households of a person affected by SMD compared to households without a person with SMD (Table 2).

\section{Incidence and intensity of catastrophic payments}

With the threshold set at $10 \%$ of total consumption expenditure, $20.3 \%$ (95\% CI 15.6, 25.9) of households of a person with SMD and 15.6\% (95\% CI 10.0, 23.5) of comparison households experienced catastrophic payments (Table 3). With the threshold set at 25\% of household total consumption, the same trend emerged, whereby $4.6 \%$ among households of a persons with SMD compared to $2.7 \%$ among comparison households incurred catastrophic health expenditure.

At a threshold level of $40 \%+$ of non-food expenditure (capacity to pay), the level of catastrophic payments was $32.2 \%$ (95\% CI 26.6, 38.4) for households of a person with SMD and 18.2\% (95\% CI 12.1, 26.4) for comparison households; Pearson $\mathrm{Chi}^{2}$ (1) 7.592, $\mathrm{p}=0.006$.

The proportion of mean positive overshoot (MPO) at the $40 \%$ threshold level was as high as $21.2 \%$ for households of a person with SMD. In comparison households, the proportion was $15.9 \% ; \mathrm{p}=0.230$ (Table 3 ).

\section{Determinants of catastrophic expenditure and coping strategies}

In the multivariable model, the odds of experiencing catastrophic OOP health payments were significantly higher for households of a person with SMD (adjusted odds ratio (aOR 1.5; 95\% CI 1.0, 2.7; $\mathrm{p}=0.041$ ), households in the lowest consumption quintile (aOR 10.8; 
Table 1 Background characteristics of households

\begin{tabular}{|c|c|c|c|}
\hline Household characteristics & $\begin{array}{l}\text { Households of person with severe } \\
\text { mental disorder (SMD) }(n=290)\end{array}$ & $\begin{array}{l}\text { Comparison households } \\
\text { without person with SMD }(n=289)\end{array}$ & p-value \\
\hline \multicolumn{4}{|l|}{ Socio-demographic and economic } \\
\hline Household members (N) & 1513 & 1522 & \\
\hline Household size, mean (SD) & $5.2(2.2)$ & $5.3(2.1)$ & 0.508 \\
\hline Household composition, mean (SD) ${ }^{\mathrm{a}}$ & $2.8(0.9)$ & $2.7(0.8)$ & 0.915 \\
\hline Mean number of adults in household & $3.2(1.3)$ & $2.9(1.1)$ & 0.004 \\
\hline Children younger than 15 years, mean (SD) & $1.9(1.7)$ & $2.3(1.6)$ & 0.004 \\
\hline \multicolumn{4}{|l|}{ Residence, $\mathrm{n}(\%)$} \\
\hline Urban & $55(18.9)$ & $53(18.3)$ & 0.847 \\
\hline Rural & $235(81.0)$ & $236(81.7)$ & \\
\hline \multicolumn{4}{|l|}{ Gender, n (\%) } \\
\hline Male & $210(72.7)$ & $223(78.0)$ & 0.140 \\
\hline Female & $79(27.3)$ & $63(22.0)$ & \\
\hline Head age (years), mean (SD) & $49.5(14.2)$ & $49.9(14.0)$ & 0.867 \\
\hline \multicolumn{4}{|l|}{ Head marital status, n (\%) } \\
\hline Never married & $20(6.9)$ & $5(1.7)$ & 0.007 \\
\hline Married & $205(70.9)$ & $223(77.7)$ & \\
\hline Separated/divorced/widowed & $64(22.1)$ & $59(20.5)$ & \\
\hline \multicolumn{4}{|l|}{ Head education, $n(\%)$} \\
\hline No formal education & $185(63.7)$ & $179(61.9)$ & 0.788 \\
\hline Primary education & $76(26.2)$ & $83(28.7)$ & \\
\hline More than primary & $29(10.0)$ & $27(9.3)$ & \\
\hline Head with health insurance, $n$ (\%) & $3(1.0)$ & $8(2.7)$ & 0.262 \\
\hline Annual median (IQR) food consumption ${ }^{b}$ & $6087.8(3785.5,9533.3)$ & $6240.0(4356.7,10,111.1)$ & 0.868 \\
\hline Annual median (IQR) non-food consumption ${ }^{b}$ & $1570.0(744.2,3179.1)$ & $1627.5(680.0,3235.5)$ & 0.803 \\
\hline Annual median (IQR) health consumption ${ }^{\mathrm{b}}$ & $290.9(166.6,678.2)$ & $355.5(195.2,733.3)$ & 0.308 \\
\hline \multicolumn{4}{|l|}{ Consumption quintile } \\
\hline Lowest & $62(21.4)$ & $52(17.9)$ & 0.613 \\
\hline Low & $64(22.1)$ & $57(19.7)$ & \\
\hline Middle & $54(18.6)$ & $63(21.8)$ & \\
\hline High & $54(18.6)$ & $63(21.8)$ & \\
\hline Highest & $55(19.0)$ & $54(18.6)$ & \\
\hline \multicolumn{4}{|l|}{ Clinical characteristics } \\
\hline WHODAS, median (IQR) & $52.7(31.9,69.4)$ & $5.5(0.0,19.4)$ & 0.000 \\
\hline
\end{tabular}

WHODAS score for the index patient and for the interviewed household member in the comparison group

WHODAS: World Health Organization Disability Assessment Schedule; IQR: inter-quartile range; SD: standard deviation

${ }^{a}$ Adult equivalent

b Birr; US\$1 = Birr 20.69 (2015)

95\% CI 3.8, 30.5; p<0.001) compared to those in the highest quintile, and in households with a member aged 60 years and above (aOR 1.2; 95\% CI 1.1, 2.2; $\mathrm{p}=0.047$ ). The odds of incurring catastrophic OOP health payments was lower for households with more members (aOR 0.6; 95\% CI 0.4, 0.9; $\mathrm{p}=0.021$ ). There was no significant difference in the odds of incurring catastrophic health payments with respect to area of residence, gender and educational status of the head of the household (Table 4).

\section{Household satisfaction in livelihood, financial difficulties} and coping

As shown in Table 5, only $8.7 \%$ (95\% CI 5.1, 12.3) of households of a person with SMD were satisfied with their financial status compared with $19.1 \%$ (95\% CI $11.8,26.4 ; \mathrm{p}=0.005)$ among households with no person with SMD. In households of a person with SMD, just 10.3\% (95\% CI 6.4, 14.2) perceived their household income to be enough to meet their livelihood needs, compared to $24.3 \%$ (95\% CI $16.3,32.3 ; \mathrm{p}=0.001)$ in 
Table 2 Household expenditure categories

\begin{tabular}{|c|c|c|c|c|c|}
\hline \multirow[t]{2}{*}{ Consumption category } & \multicolumn{2}{|c|}{$\begin{array}{l}\text { Households of person with SMD } \\
(n=290)\end{array}$} & \multicolumn{2}{|c|}{$\begin{array}{l}\text { Comparison households } \\
\text { without person with SMD }(n=289)\end{array}$} & \multirow[t]{2}{*}{ p-value } \\
\hline & $\%$ & $95 \% \mathrm{Cl}$ & $\%$ & $95 \% \mathrm{Cl}$ & \\
\hline \multicolumn{6}{|l|}{$\%$ of total consumption ${ }^{a}$} \\
\hline All food items & 75.4 & $(73.5,77.4)$ & 77.0 & $(75.1,79.0)$ & 0.202 \\
\hline Housing and livelihood regular expenses & 15.2 & $(13.5,16.9)$ & 15.7 & $(13.9,17.4)$ & 0.243 \\
\hline Big household expenditures & 3.1 & $(1.7,4.6)$ & 3.4 & $(1.6,6.1)$ & 0.351 \\
\hline Health expenditures & 6.9 & $(5.8,8.0)$ & 5.7 & $(4.5,6.9)$ & 0.151 \\
\hline \multicolumn{6}{|l|}{$\%$ of health payments } \\
\hline Consultation & 16.7 & $(13.9,19.4)$ & 16.3 & $(11.3,21.3)$ & 0.475 \\
\hline Medication & 74.1 & $(70.7,77.4)$ & 71.1 & $(65.8,76.5)$ & 0.427 \\
\hline Investigations & 29.6 & $(23.2,36.0)$ & 26.4 & $(20.5,32.4)$ & 0.846 \\
\hline
\end{tabular}

Food items (staple foods, vegetable, fruit, spices etc.), regular household expenses (electricity, water, cooking, renting, clothing, transport, etc.), Big expenditure include (education, durable goods, cultural ceremonies, entertainment, tax etc.); health expenditure include expense on (outpatient consultation, medication, investigations, hospitalization, medical appliances, ambulance, etc.)

a Adult equivalent

Table 3 Incidence and intensity of catastrophic expenditure for different thresholds

\begin{tabular}{|c|c|c|c|c|c|c|c|c|}
\hline \multirow[t]{2}{*}{ Sample } & \multicolumn{6}{|c|}{ Threshold } & \multirow{2}{*}{$\begin{array}{l}\text { Overshoot } \\
\text { at } 10 \%\end{array}$} & \multirow{2}{*}{$\begin{array}{l}\text { Mean positive } \\
\text { overshoot } \\
\text { at } 10 \%\end{array}$} \\
\hline & $5 \%$ & $10 \%$ & $15 \%$ & $20 \%$ & $25 \%$ & $40 \%$ & & \\
\hline \multicolumn{9}{|l|}{ As a proportion of total consumption } \\
\hline $\mathrm{HH}$ of a person with SMD & 42.7 & 20.3 & 16.5 & 12.1 & 4.5 & 1.2 & 1.9 & 9.7 \\
\hline HH without a person with SMD & 41.7 & 15.6 & 15.4 & 12.0 & 2.6 & 0.0 & 1.2 & 7.6 \\
\hline \multirow[t]{2}{*}{ Sample } & \multicolumn{6}{|c|}{ Threshold } & \multirow{2}{*}{$\begin{array}{l}\text { Overshoot } \\
\text { at } 40 \%+\end{array}$} & \multirow{2}{*}{$\begin{array}{l}\text { Mean positive } \\
\text { overshoot } \\
\text { at } 40 \%+\end{array}$} \\
\hline & $5 \%$ & $10 \%$ & $15 \%$ & $20 \%$ & $25 \%$ & $40 \%$ & & \\
\hline \multicolumn{9}{|l|}{ As a proportion of capacity to pay } \\
\hline $\mathrm{HH}$ of a person with SMD & $89.6^{*}$ & 74.3 & 65.7 & 62.2 & 48.3 & $32.2^{* *}$ & $6.7^{*}$ & 21.2 \\
\hline HH without a person with SMD & 80.8 & 65.2 & 57.5 & 52.3 & 38.2 & 18.2 & 2.9 & 15.9 \\
\hline
\end{tabular}

$\mathrm{HH}$ : household

${ }^{*} \mathrm{p}<0.05$; ${ }^{* *} \mathrm{p}<0.01$

households without a person with SMD. Households of a person with SMD were also less likely to be satisfied with their livelihoods $(\mathrm{p}<0.001)$.

See Additional file 2: Table S1 for unadjusted and Table 6 for adjusted multivariable logistic regression results on coping strategies that household employed to respond to financial stress. The sale of assets was a common strategy in the study population. However, households with a person with SMD were less likely to sell assets (aOR 0.4; 95\% CI 0.2, 0.7; $\mathrm{p}=0.009$ ) compared to the households without a person with SMD.

The odds of coping by reducing food consumption (aOR 3.3; 95\% CI 1.8, 6.0; $\mathrm{p}<0.001$ ), withdrawing children from school (aOR 3.1; 95\% CI 1.4, 6.7; $\mathrm{p}=0.003$ ), obtaining assistance from relatives (aOR 2.4 95\% CI 1.4,
$4.1 ; \mathrm{p}=0.001)$, reducing the frequency of medical visits (aOR 5.6; 95\% CI 2.4, 13.0; $\mathrm{p}<0.001$ ) and taking on extra work $(\mathrm{aOR} 1.8$; 95\% CI 1.1, 3.2; $\mathrm{p}=0.019)$ were higher for households of a person with SMD than comparison households (Table 6).

Households in the lowest quintile for expenditure had the highest odds of coping through reduction of food consumption (aOR 4.1; 95\% CI 1.8, 9.2; $\mathrm{p}=0.001)$ and medical visits (aOR 10.2; 95\% CI 3.7, 27.9; $\mathrm{p}=0.001$ ) compared to the wealthiest group (Table 6).

Urban households were more likely to draw up accounts at shops (aOR 3.0; 95\% CI 1.6, 5.4; $\mathrm{p}<0.001$ ), households in the lowest wealth quintile had greater odds of taking on extra work (aOR 2.4; 95\% CI 1.3, 4.4; $\mathrm{p}=0.014)$ and male household heads were significantly 
Table 4 Factors associated with catastrophic health payments at the $40 \%+$ threshold capacity to pay among households with a person with SMD and comparison households

\begin{tabular}{|c|c|c|c|c|c|}
\hline Factors & $\begin{array}{l}\text { Monthly OOP } \\
\text { payment in Birr, } \\
\text { mean (SD) }\end{array}$ & $\begin{array}{l}\text { Share of health payment } \\
\text { as } \% \text { of non-food } \\
\text { consumption }\end{array}$ & $\begin{array}{l}\text { OOPCHE } \\
(40 \%+)\end{array}$ & $\begin{array}{l}\text { Unadjusted model } \\
\text { Odds ratio }(95 \% \mathrm{Cl})\end{array}$ & $\begin{array}{l}\text { Adjusted model } \\
\text { Odds ratio }(95 \% \mathrm{Cl})\end{array}$ \\
\hline Households of person with SMD & $50.6(82.1)$ & 30.6 & 32.2 & $2.1(1.2,3.6)^{* *}$ & $1.5(1.0,2.7)^{*}$ \\
\hline $\begin{array}{l}\text { Households without person with } \\
\text { SMD }\end{array}$ & $51.7(61.0)$ & 22.7 & 18.2 & $1.00^{\mathrm{a}}$ & $1.00^{\mathrm{a}}$ \\
\hline Household size & & & & $0.5(0.4,0.7)^{* * *}$ & $0.6(0.4,0.9)^{* *}$ \\
\hline \multicolumn{6}{|l|}{ Age $\geq 60$ years in $\mathrm{HH}$} \\
\hline Yes & $50.0(78.8)$ & 29.1 & 33.0 & $1.4(0.9,2.3)$ & $1.2(1.1,2.2)^{*}$ \\
\hline No & $50.5(64.3)$ & 27.2 & 25.1 & $1.00^{\mathrm{a}}$ & $1.00^{\mathrm{a}}$ \\
\hline \multicolumn{6}{|l|}{ Area of residence } \\
\hline Urban & $58.1(74.2)$ & 26.6 & 27.1 & $0.9(0.5,1.7)$ & $1.3(0.6,2.5)$ \\
\hline Rural & $49.2(76.3)$ & 28.4 & 27.8 & $1.00^{\mathrm{a}}$ & $1.00^{\mathrm{a}}$ \\
\hline \multicolumn{6}{|l|}{ Gender of the head of the $\mathrm{HH}$} \\
\hline Male & $49.9(75.5)$ & 26.7 & 25.4 & $0.6(0.3,1.1)$ & $0.9(0.5,1.7)$ \\
\hline Female & $50.9(71.3)$ & 31.0 & 34.0 & $1.00^{\mathrm{a}}$ & $1.00^{\mathrm{a}}$ \\
\hline \multicolumn{6}{|l|}{ Household head education } \\
\hline No formal education & $44.2(54.3)$ & 27.1 & 24.3 & $0.8(0.3,1.8)$ & $0.7(0.3,1.9)$ \\
\hline Primary education & $63.0(106.0)$ & 29.8 & 35.3 & $1.4(0.6,3.2)$ & $1.5(0.6,3.9)$ \\
\hline More than primary education & $59.8(88.4)$ & 28.6 & 27.7 & $1.00^{\mathrm{a}}$ & $1.00^{\mathrm{a}}$ \\
\hline \multicolumn{6}{|l|}{ Children in the household } \\
\hline 0 & $54.8(72.0)$ & 36.0 & 40.5 & $2.6(1.4,4.7)^{* *}$ & $1.2(0.5,3.0)$ \\
\hline $1-2$ & $56.9(73.3)$ & 29.0 & 27.8 & $1.4(0.8,2.5)$ & $0.8(0.4,1.7)$ \\
\hline 3 and more & $43.5(80.0)$ & 22.8 & 20.6 & $1.00^{\mathrm{a}}$ & $1.00^{\mathrm{a}}$ \\
\hline \multicolumn{6}{|l|}{ Consumption quintile } \\
\hline Quintile 1 (lowest) & $21.2(14.3)$ & 38.0 & 45.7 & $9.5(3.7,24.0)^{* * *}$ & $10.8(3.8,30.5)^{* * *}$ \\
\hline Quintile 2 & $34.5(32.4)$ & 34.8 & 38.0 & $6.9(2.7,17.5)^{* * *}$ & $8.2(2.9,22.9)^{* * *}$ \\
\hline Quintile 3 & $59.7(79.4)$ & 29.6 & 29.3 & $4.6(1.8,11.7)^{* *}$ & $5.7(2.0,15.8)^{* *}$ \\
\hline Quintile 4 & $60.1(70.0)$ & 26.7 & 25.6 & $3.8(1.5,9.9)^{* *}$ & $4.9(1.7,13.5)^{* *}$ \\
\hline Quintile 5 (highest) & $67.7(110.5)$ & 16.0 & 8.1 & $1.00^{\mathrm{a}}$ & $1.00^{\mathrm{a}}$ \\
\hline
\end{tabular}

OOPCHE: out-of-pocket catastrophic health expenditure; $\mathrm{HH}$ : household

${ }^{*} \mathrm{p}<0.05$; ${ }^{* *} \mathrm{p}<0.01$; ${ }^{* * *} \mathrm{p}<0.001$; US\$1 = Birr 20.69 (2015)

${ }^{a}$ Reference group

less likely to experience consumption reduction (aOR $0.4 ; 95 \%$ CI $0.2,0.8 ; \mathrm{p}=0.009)$ and interrupt medical visits (aOR 0.4; 95\% CI 0.1, 0.7; $\mathrm{p}=0.008$ ), respectively (Table 6).

\section{Discussion}

In our study, the incidence rate of catastrophic health expenditure at various thresholds of household total expenditure and capacity to pay was consistently higher for households of a person with SMD compared to households without a person with SMD. In both households with and without SMD, the level of catastrophic health spending was high compared to the average for the African region of $11.4 \%$ [47]. Furthermore, at a $25 \%+$ threshold of total expenditure, the proportion of households experiencing catastrophic expenditure was almost two times higher for households with SMD compared with households without an affected person. Based on the threshold of $40 \%+$ of consumption-based capacity to pay, our result remains significantly higher for households of a person with SMD.

Similarly, Zuvekas and Selden [48] in USA, Patel et al. [7] in India and Zergaw et al. [49] in Ethiopia reported that families with one or more member experiencing mental health problems were more likely to have high out-of-pocket spending compared with the control groups. Moreover, this study is consistent with findings from an earlier study from the USA that reported people with bipolar disorder incurred over four times greater costs compared with the non-bipolar group [50]. 
Table 5 Household satisfaction in livelihood, financial difficulties and coping

\begin{tabular}{|c|c|c|c|c|c|}
\hline \multirow[t]{3}{*}{ Financial difficulties and coping } & \multicolumn{5}{|c|}{ Households with out-of-pocket health payments } \\
\hline & \multicolumn{2}{|c|}{$\begin{array}{l}\text { Households of person with SMD } \\
(n=241)\end{array}$} & \multicolumn{2}{|c|}{$\begin{array}{l}\text { Households without person with SMD } \\
(n=115)\end{array}$} & \multirow[t]{2}{*}{ p-value } \\
\hline & No & $\%(95 \% \mathrm{Cl})$ & No & $\%(95 \% \mathrm{Cl})$ & \\
\hline \multicolumn{6}{|c|}{ Household financial situation and livelihood } \\
\hline Perceive income is enough & 25 & $10.3(6.4,14.2)$ & 28 & $24.3(16.3,32.3)$ & 0.001 \\
\hline Satisfied with financial situation & 21 & $8.7(5.1,12.3)$ & 22 & $19.1(11.8,26.4)$ & 0.005 \\
\hline Satisfied with livelihood & 89 & $36.9(30.7,40.0)$ & 71 & $61.7(52.7,70.7)$ & 0.000 \\
\hline \multicolumn{6}{|l|}{ Coping strategies implemented } \\
\hline Drew up accounts at shops & 71 & $29.4(23.6,35.2)$ & 26 & $22.6(14.8,30.3)$ & 0.175 \\
\hline Loan from bank/financial institution & 57 & $23.6(18.2,29.0)$ & 25 & $21.7(14.0,29.3)$ & 0.689 \\
\hline Cut down food consumption & 105 & $43.5(37.2,49.8)$ & 20 & $17.3(10.3,24.4)$ & 0.000 \\
\hline Reduced medical visits & 68 & $28.2(22.4,33.9)$ & 7 & $6.0(1.6,10.5)$ & 0.000 \\
\hline Asked help from community & 25 & $10.3(6.4,14.2)$ & 6 & $5.2(1.0,9.3)$ & 0.107 \\
\hline Asked help from family & 93 & $38.5(32.3,44.7)$ & 25 & $21.7(14.0,29.3)$ & 0.002 \\
\hline Withdrew children from school & 56 & $23.2(17.8,28.6)$ & 9 & $7.8(2.8,12.8)$ & 0.000 \\
\hline Took on extra work & 92 & $38.1(31.9,44.3)$ & 26 & $22.6(14.8,30.3)$ & 0.004 \\
\hline Used savings & 23 & $9.5(5.8,13.2)$ & 12 & $10.4(4.7,16.1)$ & 0.792 \\
\hline Sold assets & 152 & $66.3(60.2,72.5)$ & 86 & $80.3(72.7,88.0)$ & 0.009 \\
\hline More than one strategy & 159 & $65.9(59.9-71.9)$ & 45 & $39.5(30.0-48.1)$ & 0.000 \\
\hline
\end{tabular}

Likewise, in São Paulo [51] and in the USA [52], having a mental disorder was strongly correlated with higher health care payments. The higher burden of catastrophic health payments in households of a person with SMD can be explained by the financing structure of the available health system, the scarcity of locally available treatment services, and the marked disabling nature of the disorder that may increase health service use which in turn leads to high OOP expenditure.

We found evidence of regressive health spending, whereby households in the lowest quintile of socioeconomic status paid $38.0 \%$ of their capacity to pay compared to only $16.0 \%$ for the highest quintile. The differences found for catastrophic health spending based on capacity to pay in relation to mental health status were significant and also followed a pattern linked to socio-economic status of the household. These results indicate that catastrophic health spending affects more households of a person with SMD and the poorest households. In the absence of financial protection (fewer than $3 \%$ of households in our study were enrolled in a social protection scheme), catastrophic out-of-pocket payments will further increase the number of households of a person with SMD falling into poverty, as well as potentially act as a deterrent from using services. Having an older household member was also associated with catastrophic health expenditure. In other studies, the presence of elderly members in the household was also found to lead to catastrophic health expenditure [53-55]. This may be because older adult members require more health care that may result in higher health expenditure. Nonetheless, there was no statistically significant difference between gender, educational level of the head of the household, residential location, children in the household and incurring catastrophic health expenditure. Previous studies on nonmental health problems reported mixed findings [53, 56-59].

This study has shown that mental health status, demographic and economic factors play an important role in the coping strategy adopted by households in Sodo. Our study indicated that the probability of withdrawing children from school was significantly higher for households of a person with SMD. A number of studies have found that children are taken out of school during times of illness in order to take up the slack in the workload in their families [12, 20, 22, 60]. A recent population-based cohort study in Ethiopia demonstrated that maternal common mental disorder was associated with child school dropout and absenteeism [61]. For people with SMD, the impact on child education may be more enduring due to the tendency for the illness to persist or recur. From an economic point of view, such action in response to healthcare costs will have a long-term impact on investment in human capital which may have serious implications for the education of future generations. 
Table 6 Adjusted odds of coping strategies for financial difficulties by mental health disorder and covariates

\begin{tabular}{|c|c|c|c|c|c|c|c|c|c|}
\hline \multirow[t]{3}{*}{ Characteristics } & \multirow{3}{*}{$\begin{array}{l}\text { Total } \\
\text { by subgroup }\end{array}$} & \multicolumn{8}{|c|}{ Coping strategies implemented for financial constraint } \\
\hline & & $\begin{array}{l}\text { Sold } \\
\text { assets } \\
(n=238)\end{array}$ & $\begin{array}{l}\text { Drew } \\
\text { up accounts } \\
\text { at shops } \\
(n=97)\end{array}$ & $\begin{array}{l}\text { Cut } \\
\text { down food } \\
\text { consumption } \\
(n=125)\end{array}$ & $\begin{array}{l}\text { Withdrew } \\
\text { children } \\
\text { from school } \\
(n=65)\end{array}$ & $\begin{array}{l}\text { Relatives/ } \\
\text { family } \\
\text { assistance } \\
(n=118)\end{array}$ & $\begin{array}{l}\text { Reduce } \\
\text { medical } \\
\text { visits } \\
(n=75)\end{array}$ & $\begin{array}{l}\text { Used } \\
\text { savings } \\
(n=35)\end{array}$ & $\begin{array}{l}\text { Took } \\
\text { on extra } \\
\text { work } \\
(n=118)\end{array}$ \\
\hline & & $\begin{array}{l}\text { AOR }(95 \% \\
C I)\end{array}$ & $\begin{array}{l}\text { AOR }(95 \% \\
\mathrm{CI})\end{array}$ & AOR $(95 \% \mathrm{Cl})$ & $\begin{array}{l}\text { AOR }(95 \% \\
C I)\end{array}$ & $\begin{array}{l}\text { AOR }(95 \% \\
C I)\end{array}$ & $\begin{array}{l}\text { AOR }(95 \% \\
C I)\end{array}$ & $\begin{array}{l}\text { AOR }(95 \% \\
\text { CI) }\end{array}$ & $\begin{array}{l}\text { AOR }(95 \% \\
\text { CI) }\end{array}$ \\
\hline $\begin{array}{l}\text { HH of person } \\
\text { with SMD }\end{array}$ & 241 & $\begin{array}{c}0.4(0.2 \\
0.9)^{*}\end{array}$ & $1.5(0.8,2.7)$ & $3.3(1.8,6.0)^{* * *}$ & $3.1(1.4,6.7)^{* *}$ & $\begin{array}{r}2.4(1.4 \\
4.1)^{* *}\end{array}$ & $\begin{array}{l}5.6(2.4 \\
13.0)^{* * *}\end{array}$ & $0.8(0.3,1.8)$ & $1.8(1.1,3.2)^{*}$ \\
\hline $\begin{array}{l}\text { HH without } \\
\text { person with } \\
\text { SMD }\end{array}$ & 115 & $1.00^{\mathrm{a}}$ & $1.00^{\mathrm{a}}$ & $1.00^{\mathrm{a}}$ & $1.00^{\mathrm{a}}$ & $1.00^{\mathrm{a}}$ & $1.00^{\mathrm{a}}$ & $1.00^{\mathrm{a}}$ & $1.00^{\mathrm{a}}$ \\
\hline \multicolumn{10}{|l|}{ Residence } \\
\hline Urban & 70 & $\begin{array}{c}0.08(0.04 \\
0.17)^{* * *}\end{array}$ & $\begin{array}{l}3.0(1.6 \\
5.4)^{* * *}\end{array}$ & $1.1(0.6,2.1)$ & $0.9(0.4,1.9)$ & $0.9(0.5,1.7)$ & $1.0(0.4,2.1)$ & $0.7(0.2,2.2)$ & $\begin{array}{r}2.4(1.3 \\
4.4)^{* *}\end{array}$ \\
\hline Rural & 286 & $1.00^{\mathrm{a}}$ & $1.00^{\mathrm{a}}$ & $1.00^{\mathrm{a}}$ & $1.00^{\mathrm{a}}$ & $1.00^{\mathrm{a}}$ & $1.00^{\mathrm{a}}$ & $1.00^{\mathrm{a}}$ & $1.00^{\mathrm{a}}$ \\
\hline \multicolumn{10}{|l|}{ Gender } \\
\hline Male & 262 & $1.4(0.8,2,7)$ & $0.6(0.3,1.1)$ & $0.4(0.2,0.8)^{* *}$ & $1.1(0.5,2.1)$ & $1.1(0.6,1.9)$ & $\begin{array}{r}0.4(0.1 \\
0.7)^{* *}\end{array}$ & $1.3(0.5,3.4)$ & $1.3(0.8,2.3)$ \\
\hline Female & 91 & $1.00^{\mathrm{a}}$ & $1.00^{\mathrm{a}}$ & $1.00^{\mathrm{a}}$ & $1.00^{\mathrm{a}}$ & $1.00^{\mathrm{a}}$ & $1.00^{\mathrm{a}}$ & $1.00^{\mathrm{a}}$ & $1.00^{\mathrm{a}}$ \\
\hline \multicolumn{10}{|c|}{ Household consumption } \\
\hline $\begin{array}{l}\text { Quintile } 1 \\
\text { (lowest) }\end{array}$ & 58 & $0.6(0.2,1.5)$ & $1.7(0.7,4.0)$ & $4.1(1.8,9.2)^{* *}$ & $1.9(0.7,5.0)$ & $1.0(0.4,2.2)$ & $\begin{array}{l}10.2(3.7 \\
27.9)^{* * *}\end{array}$ & $1.8(0.5,5.6)$ & $2.6(1.2,5.8)^{*}$ \\
\hline Quintile 2 & 63 & $0.7(0.2,1.6)$ & $1.1(0.5,2.5)$ & $2.6(1.1,5.7)^{*}$ & $1.8(0.7,4.6)$ & $0.9(0.4,1.9)$ & $\begin{array}{l}4.9(1.7 \\
13.6)^{* *}\end{array}$ & $1.0(0.3,3.5)$ & $\begin{array}{r}2.9(1.3 \\
6.2)^{* *}\end{array}$ \\
\hline Quintile 3 & 75 & $0.5(0.2,1.2)$ & $1.4(0.6,3.0)$ & $3.2(1.5,7.0)^{* *}$ & $1.6(0.6,4.0)$ & $1.4(0.7,2.8)$ & $\begin{array}{l}6.9(2.4 \\
19.2)^{* * *}\end{array}$ & $1.3(0.4,3.8)$ & $2.3(1.1,4.8)^{*}$ \\
\hline Quintile 4 & 74 & $0.9(0.4,2.2)$ & $1.6(0.7,3.3)$ & $1.5(0.6,3.3)$ & $1.2(0.4,3.1)$ & $1.2(0.6,2.4)$ & $\begin{array}{l}5.0(1.7 \\
14.1)^{* *}\end{array}$ & $1.1(0.3,3.6)$ & $1.8(0.8,3.7)$ \\
\hline $\begin{array}{l}\text { Quintile } 5 \\
\text { (highest) }\end{array}$ & 86 & $1.00^{\mathrm{a}}$ & $1.00^{\mathrm{a}}$ & $1.00^{\mathrm{a}}$ & $1.00^{\mathrm{a}}$ & $1.00^{\mathrm{a}}$ & $1.00^{\mathrm{a}}$ & $1.00^{\mathrm{a}}$ & $1.00^{\mathrm{a}}$ \\
\hline
\end{tabular}

The model was run separately for each coping strategy using the same set of independent variables

$\mathrm{Cl}$ : 95\% confidence interval; AOR: Adjusted odds ratio; $\mathrm{HH}$ : household

${ }^{*} \mathrm{p}<0.05,{ }^{* *} \mathrm{p}<0.01,{ }^{* * *} \mathrm{p}<0.001$

a Reference group

We had shown previously in the same sample that households of people with SMD are more likely to be severely food insecure than comparison households [62]. Our finding that households of a person with SMD were more likely to reduce their daily food consumption to cope with healthcare costs indicates that catastrophic health costs are one pathway towards food insecurity. When OOP payments comprise a large share of household budgets, households are at risk of sacrificing current consumption and experience food insecurity to pay for medical costs [60,63-65]. Previous study on coping strategies for cost of illness in Ethiopia found that roughly one-third of households had to sacrifice other essential spending to pay for medical treatment [23]. Therefore, programmes that reduce out-of-pocket payments may indirectly improve access to food and nutrition.
Severe mental disorders are often chronic or recurrent, with a need for ongoing medical care for the best outcome. However, the results indicate that households of a person with SMD were more likely to adopt cost prevention strategies, like reducing medical visits, compared to comparison households, at the time when they most needed to access services. This strategy may threaten the person's recovery from illness. Studies on non-communicable diseases reported similar findings $[60,66,67]$.

Selling of assets in households of a person with SMD tended to be significantly lower than comparison households. This is explained by the possession of fewer assets that could be sold by these households [68]. Likewise, despite greater need, borrowing or taking a loan was not a common strategy adopted by households of a person with SMD. This might be because households with a person with SMD have less capacity to get loans because 
they cannot guarantee repayments. Nonetheless, previous studies on coping strategies for cost of illness in Ethiopia have found that roughly one-third had to adopt a cost management strategy, such as borrowing, selling assets or mortgaging a crop [23, 69]. Empirical evidence shows that borrowing and selling assets to cope with medical costs ranged from 23\% of households in Zambia to $68 \%$ in Burkina Faso [18]. In India, half of the out-ofpocket expenditure made by households for psychiatric disorders came from loans [70]. This is not in line with our findings. Studies in the literature reported that coping strategies that can be adopted for financial stress are likely to be context and country specific $[71,72]$.

A transfer of either goods/money from friends and relatives was reported to be a common strategy in households of people with SMD in our study. Empirical evidence from low-and middle-income countries indicates that assistance from relatives and friends is very common when household members face illness, and that this acts as an insurance mechanism rather than as credit [73].

The least common coping response by households of a person with SMD to the financial stress in our data was the use of savings. This may reflect the fact that households of a person with SMD rarely have savings. Gresenz and Sturm [74] found that, compared to mentally healthy individuals, mentally ill individuals are $75 \%$ less likely to have any savings.

\section{Strengths and limitations}

Our study is a population-based study of people with a clinically confirmed diagnosis of SMD using standardized measures. Most previous studies of health expenditure in people with mental health problems in LMICs have focused on depression/anxiety [7] or relied upon facility-based studies which are subject to selection bias [75]. The inclusion of matched comparisons without the condition in our study enabled us to estimate the net effect of SMD on out-of-pocket health expenditures. This approach is recommended by WHO in estimating economic consequences of a disease [76]. Furthermore, we estimated expenditures in a comprehensive and systematic way and used households as the preferred unit of analysis for assessing out-of-pocket payments because decisions about treatment and coping are based on negotiations within the household.

Limitations of the study are that self-reported household consumption expenditures may not be accurate due to recall bias. We did not include costs associated with treatment seeking, like transportation, which may lead to underestimation of the financial impact of out-of-pocket payments for health care on households. The study was based on a cross-sectional survey, so the temporal association between severe mental disorder and catastrophic expenditure was not established. Hence, future research could examine how OOP burdens vary over time with service utilization patterns.

\section{Conclusions}

Catastrophic out-of-pocket health expenditures in households of a person with SMD at any threshold were high and associated with financial coping strategies which may lead to poorer health outcomes, entrenchment of poverty, and intergenerational disadvantage. Therefore, policy interventions aimed at addressing the high burden of OOP payments among vulnerable households should be in place. Such mechanisms can include: subsidies, cash transfers or exemption mechanisms for accessing health care and the scale up of integrated mental health care, as well as risk pooling mechanism such as communitybased health insurance [77].

\section{Additional files}

Additional file 1: Figure S1. Patient recruitment flow

Additional file 2: Table S1. Unadjusted odds of coping strategies for financial difficulties by mental health disorder and covariates.

\section{Abbreviations}

Emerald: emerging mental health systems in low- and middle-income countries; GDP: gross domestic product; LMICs: low- and middle-income countries; OCRPIT: operational criteria checklist for psychotic illness and affective illness; OOP: out-of-pocket; PRIME: PRogramme for Improving Mental health carE; SAGE: Study on global Ageing and adult health; SMD: severe mental disorder; WHO: World Health Organization; WHODAS: WHO disability assessment schedule.

\section{Acknowledgements \\ We appreciate all participants in the study for their time and effort.}

\section{Disclaimer}

DC is a staff member of the World Health Organization. The authors alone are responsible for the views expressed in this publication and they do not necessarily represent the decisions, policy or views of the World Health Organization.

\section{Authors' contributions}

$Y H, D H, C L, S D, D C$ and $C H$ designed the study. YH, SD analyzed the data. YH drafted the manuscript and received critical feedback from (DH, KT, AF, AA,

$\mathrm{GM}, \mathrm{CL}, \mathrm{SD}, \mathrm{DC}$ and $\mathrm{CH}$ ). All authors read and approved the final manuscript.

\section{Funding}

The research leading to these results was funded by Addis Ababa University and the Emerald project through a grant from European Union's Seventh Framework Programme (FP7/2007-2013) under Grant Agreement No. 30598. This study was also partly funded by the PRogramme for Improving Mental health carE (PRIME), through a grant from the UK Department for International Development [201446]. The views expressed do not necessarily reflect the UK Government's official policies. The funders had no role in study design, data collection, analysis, decision to publish and preparation of the manuscript.

\section{Availability of data and materials}

The data are being used for a Ph.D. student $(\mathrm{YH})$ for his thesis and are not, therefore, available at the present time to the general public. The data may be 
requested from the corresponding author for verification of the analyses in this paper on a reasonable request.

\section{Ethics approval and consent to participate}

Ethical approval was obtained from the Institutional Review Board (IRB) of the College of Health Sciences, Addis Ababa University (Reference number 074/13/Psy), King's College London (KCL), and the Ethics Review Committee of the World Health Organization (RPC 619). Voluntary informed consent was obtained from all study participants prior to their inclusion in the study. Participants diagnosed as having SMD received health centre-based mental healthcare through PRIME.

\section{Consent for publication}

\section{Not applicable.}

\section{Competing interests}

This study is part of a Ph.D. research and the source of the funding is partially from Addis Ababa University. We declare that we have no other competing interests.

\section{Author details \\ 1 Department of Reproductive Health and Health Services Management, School of Public Health, College of Health Sciences, Addis Ababa University, Addis Ababa, Ethiopia. ${ }^{2}$ Department of Psychiatry, School of Medicine, College of Health Sciences, Addis Ababa University, Addis Ababa, Ethiopia. ${ }^{3}$ Centre for Global Mental Health, Health Service and Population Research Department, Institute of Psychiatry, Psychology and Neuroscience, King's Col- lege, London, UK. ${ }^{4}$ Alan J. Flisher Centre for Public Mental Health, Department of Psychiatry and Mental Health, University of Cape Town, Cape Town, South Africa. ${ }^{5}$ Aklilu-Lemma Institute of Pathobiology, Addis Ababa University, Addis Ababa, Ethiopia. ${ }^{6}$ Department of Mental Health and Substance Abuse, World Health Organization, Geneva, Switzerland. ${ }^{7}$ Centre for Affective Disorders, Department of Psychological Medicine, Institute of Psychiatry, Psychology and Neuroscience, King's College, London, UK.}

\section{Received: 10 August 2018 Accepted: 23 May 2019}

Published online: 01 June 2019

\section{References}

1. World Health Organization and the International Bank for Reconstruction and Development/The World Bank. Tracking universal health coverage: 2017 global monitoring report. World Health Organization and International Bank for Reconstruction and Development/The World Bank. 2017. http://www.who.int/healthinfo/universal_health_coverage/report/2017/ en. Accessed 11 Mar 2018.

2. Dixon A, McDaid D, Knapp M, Curran C. Financing mental health services in low- and middle-income countries. Health Policy Plan. 2006;21:171-82.

3. World Health Organization. Mental health atlas 2017. Geneva: World Health Organization; 2018. http://www.who.int/mental_health/evidence/ atlasmnh/en/. Accessed 9 July 2018.

4. Federal Democratic Republic of Ethiopia. Ministry of Health. Ethiopia Sixth Health Accounts. 2013/14. Addis Ababa. Ethiopia. 2017. http://apps. who.int/nha/database/DocumentationCentre/Index/en. Accessed 12 Mar 2018.

5. Alebachew A, Yusuf Y, Mann C, Berman P. Ethiopia's Progress in Health Financing and the Contribution of the 1998 Health Care and Financing Strategy in Ethiopia. Resource Tracking and Management Project. Harvard T.H. Chan School of Public Health and Breakthrough International Consultancy, PLC. Boston: Massachusetts and Addis Ababa. Ethiopia. 2015. https ://cdn1.sph.harvard.edu/wp-content/uploads/sites/1578/2013/09/HCFSReview-Report.HSPH-BIC.-FINAL-June-1-2015.pdf. Accessed 12 Mar 2018.

6. Hailemariam M, Fekadu A, Prince M, Hanlon C. Engaging and staying engaged: a phenomenological study of barriers to equitable access to mental healthcare for people with severe mental disorders in a rural African setting. Int J Equity Health. 2017;16:156.

7. Patel V, Chisholm D, Kirkwood BR, Mabey D. Prioritizing health problems in women in developing countries: comparing the financial burden of reproductive tract infections, anaemia and depressive disorders in a community survey in India. Trop Med Int Health. 2007;12(1):130-9.
8. Rahman MM, Gilmour S, Saito E, Sultana P, Shibuya K. Health-related financial catastrophe, inequality and chronic illness in Bangladesh. PLoS ONE. 2013;8(2):e56873.

9. Ringel JS, Sturm R. Financial burden and out-of-pocket expenditures for mental health across different socioeconomic groups: results from HealthCare for Communities. J Ment Health Policy Econ. 2001;4:141-50.

10. Russell S. The economic burden of illness for households in developing countries: a review of studies focusing on malaria, tuberculosis and human immuno-deficiency virus/acquired immuno-deficiency syndrome. Am J Trop Med Hyg. 2004;71(Suppl 2):147-55.

11. Xu K, Evans DB, Kawabata K, Zeramdini R, Klavus J, Murray CJ. Household catastrophic health expenditure: a multicounty analysis. Lancet. 2003;362(9378):111-7.

12. Sen B. Drivers of escape and descent: changing household fortunes in rural Bangladesh. World Dev. 2003;31(3):513-34.

13. Krishna A. Pathways out of and into poverty in 36 villages of Andhra Pradesh, India. World Dev. 2006;34(2):271-88.

14. Van Damme W, Van Leemput L, Por I, Hardeman W, Meessen B. Out-ofpocket health expenditure and debt in poor households: evidence from Cambodia. Trop Med Int Health. 2004;9(2):273-80.

15. Whitehead M, Dahlgren G, Evans T. Equity and health sector reforms: can low-income countries escape the medical poverty trap? Lancet. 2001;358(9284):833-6.

16. Mclntyre D, Thiede M, Dahlgren $G$, Whitehead M. What are the economic consequences for households of illness and of paying for health care in low- and middle-income country contexts? Soc Sci Med. 2006;62:858-65.

17. Flores G, Krishnakumar J, O’Donnell O, van Doorslaer E. Coping with health-care costs: implications for the measurement of catastrophic expenditures and poverty. Health Econ. 2008;17(12):1393-412.

18. Leive A, Xu K. Coping with out-of-pocket health payments: empirical evidence from 15 African countries. Bull World Health Organ. 2008;86(11):849-56

19. Morduch J. Income smoothing and consumption smoothing. J Econ Perspect. 1995;9(3):103-14.

20. Sauerborn R, Adams A, Hien M. Household strategies to cope with the economic costs of illness. Soc Sci Med. 1996:43(3):291-301.

21. Kruk ME, Goldmann E, Galea S. Borrowing and selling to pay for health care in low- and middle-income countries. Health Aff. 2009;28(4):1056-66.

22. Baingana F, Dabalen A, Menye E, Prywes M, Rosholm M. Mental health and socio-economic outcomes in Burundi. Health, nutrition and population (HNP) discussion paper. Washington, DC: World Bank; 2004. https:// openknowledge.worldbank.org/handle/10986/13653. Accessed 20 Mar 2018.

23. Russell S, Abdella K. Too poor to be sick: coping with the costs of illness in East Hararghe, Ethiopia. London: Save the Children, UK; 2002.

24. Wang H, Zhang L, Hsiao W. III health and its potential influence on household consumptions in rural China. Health Policy. 2006;78(2-3):167-77.

25. Wagstaff $A$. The economic consequences of health shocks: evidence from Vietnam. J Health Econ. 2007;26(1):82-100.

26. Nguyen KT, Khuat OT, Ma S, Pham DC, Khuat GT, Ruger JP. Effect of health expenses on household capabilities and resource allocation in a rural commune in Vietnam. PLoS ONE. 2012;7(10):e47423.

27. Limwattananon S, Tangcharoensathien V, Prakongsai P. Catastrophic and poverty impacts of health payments: results from national household surveys in Thailand. Bull World Health Organ. 2007;85(8):600-6.

28. Asfaw A, Von Braun J. Is consumption insured against illness? Evidence on vulnerability of households to health shocks in rural Ethiopia. Econ Dev Cult Change. 2004;53:115-29.

29. Dercon S, Hoddinott J, Woldehanna T. Shocks and consumption in 15 Ethiopian villages, 1999-2004. J Afr Econ. 2005;14:559.

30. Semrau M, Evans-Lacko S, Alem A, Ayuso-Mateos JL, Chisholm D, Gureje O, Hanlon C, Jordans M, Kigozi F, Lempp H, Lund C, Petersen I, Shidhaye R, Thornicroft G. Strengthening mental health systems in low- and middleincome countries: the Emerald programme. BMC Med. 2015;13:79.

31. Hanlon C, Luitel N, Kathree T, Murhar V, Shrivasta S, Medhin G, Ssebunnya J, Fekadu A, Petersen I, Jordans M, Kigozi F, Thornicroft G, Patel V, Tomlinson M, Lund C, Breuer E, De Silva M, Prince M. Challenges and opportunities for implementing mental health in primary care in the PRIME study: comparison of the baseline situation in five LAMIC settings. PLOS ONE. 2014:9:e88437. 
32. Sodo District Health Office. Annual health service performance report. Bue, Sodo district health office. 2017.

33. Fekadu A, Hanlon C, Medhin G, Alem A, Selamu M, Giorgis TW, Shibre T, Teferra S, Tegegn T, Breuer E, Patel V, Tomlinson M, Thornicroft G, Prince M, Lund C. Development of a scalable mental healthcare plan for a rural district in Ethiopia. Br J Psychiatry. 2016;208:s4-12. https://doi.org/10.1192/ bjp.bp.114.153676.

34. Shibre T, Kebede D, Alem A, Negash A, Kibreab S, Fekadu A, Fekadu D, Jacobsson L, Kullgren G. An evaluation of two screening methods to identify cases with schizophrenia and affective disorders in a community survey in rural Ethiopia. Int J Soc Psychiatry. 2002;48(3):200-8.

35. World Health Organisation. WHO mhGAP: mental health gap action programme: scaling up care for mental, neurological and substance use disorders. Geneva: WHO; 2008.

36. Brittain PJ, Stahl D, Rucker J, Kawadler J, Schumann G. A review of the reliability and validity of OPCRIT in relation to its use for the routine clinical assessment of mental health patients. Int J Methods Psychiatr Res. 2013;22(2):110-37.

37. Fekadu A, Medhin G, Selamu M, Hailemariam M, Alem A, Giorgis TW, Breuer E, Lund C, Prince M, Hanlon C. Population level mental distress in rural Ethiopia. BMC Psychiatry. 2014;14:194.

38. World Health Organization. World Health Organization study on global Ageing and adult health (SAGE). Geneva: World Health Organization; 2013. http://www.who.int/healthinfo/systems/sage/en/index.html. Accessed 3 Jan 2014.

39. O'Donnell O, van Doorslaer E, Wagstaff A, Lindelow M. Analyzing health equity using household survey data: a guide to techniques and their implementation. Washington, DC: The World Bank; 2008.

40. Onoka CA, Onwujekwe OE, Hanson K, Uzochukwu BS. Examining catastrophic health expenditures at variable thresholds using household consumption expenditure diaries. Trop Med Int Health. 2011;16(10):1334-41.

41. Kawabata K, Xu K, Carrin G. Preventing impoverishment through protection against catastrophic health expenditure. Bull World Health Organ. 2002;80(8):612.

42. World Health Organization (2010) The world health report-health systems financing: the path to universal coverage. http://www.who.int/ whr/en/index.html. Accessed 3 Jan 2014.

43. Wagstaff $A$, van Doorslaer E. Catastrophe and impoverishment in paying for health care: with applications to Vietnam 1993-1998. Health Econ. 2003:12(11):921-34

44. Habtamu K, Alem A, Medhin G, Fekadu A, Dewey D, Prince M, Hanlon C. Validation of the World Health Organization disability assessment schedule in people with severe mental disorders in rural Ethiopia. Health Qual Life Outcomes. 2017:15:64.

45. Lauritsen JM, Bruus M. EpiData (version 3.1). A comprehensive tool for validated entry and documentation of data. Odense: The EpiData Association; 2004.

46. StataCorpL.P. Stata/SE Version 13.1. Texas. 2014

47. Wagstaff A, Flores G, Hsu J, Smitz M-F, Chepynoga K, Buisman LR, van Wilgenburg K, Eozenou P. Progress on catastrophic health spending in 133 countries: a retrospective observational study. Lancet Glob Health. 2017. https://doi.org/10.1016/S2214-109X(17)30429-1.

48. Zuvekas SH, Selden TM. Mental health and family out-of-pocket expenditure burdens. Med Care Res Rev. 2010;67(2):194-212.

49. Zergaw A, Hailemariam D, Alem A, Kebede D. A longitudinal comparative analysis of economic and family care giver burden due to bipolar disorder. Afr J Psychiatry. 2008;11(3):191-8.

50. Lynda BC, Stender M, Giovanna D. Health care utilization and costs among privately insured patients with bipolar I disorder. Bipolar Disord. 2002:4(6):398-405.

51. ChiavegattoFilho AD, Wang YP, Coelho Campino AC, Malik AM, Viana MC, Andrade LH. Incremental health expenditure and lost days of normal activity for individuals with mental disorders: results from the São Paulo Megacity Study. BMC Public Health. 2015:15:745.

52. Nguyen MT, Chan WY, Keeler C. The association between self-rated mental health status and total health care expenditure: a cross-sectional analysis of a nationally representative sample. Medicine. 2015;94(35):e1410.
53. Barasa EW, Maina T, Ravishanka N. Assessing the impoverishing effects, and factors associated with the incidence of catastrophic health care payments in Kenya. Int J Equity Health. 2017;16:31.

54. Brinda EM, Kowal P, Attermann J, Enemark U. Health service use, out-ofpocket payments and catastrophic health expenditure among older people in India: the WHO Study on global AGEing and adult health (SAGE). J Epidemiol Community Health. 2015;69:489-94.

55. Waters HR, Anderson GF, Mays J. Measuring financial protection in health in the United States. Health Policy. 2004:69(3):339-49.

56. Ukwaja KN, Alobu I, Abimbola S, Hopewell PC. Household catastrophic payments for tuberculosis care in Nigeria: incidence, determinants, and policy implications for universal health coverage. Infect Dis Poverty. 2013;2:21.

57. Onwujekwe O, Uzochukwu B. Socio-economic and geographic differentials in costs and payment strategies for primary healthcare services in Southeast Nigeria. Health Policy. 2005;71:383-97.

58. Chuma J, Gilson L, Molyneux K. Treatment seeking behavior, cost burdens and coping strategies among rural and urban households in coastal Kenya: an equity analysis. Trop Med Int Health. 2007;12:673-86.

59. Memirie ST, Metaferia ZS, Norheim OF, Levin CE, Verguet S, Johansson KA. Household expenditures on pneumonia and diarrhoea treatment in Ethiopia: a facility-based study. BMJ Glob Health. 2017;1:e000166. https:// doi.org/10.1136/bmjgh-2016-000166.

60. Arrossi S, Matos E, Zengarini N, Roth B, Sankaranayananan R, Parkin M. The socio-economic impact of cervical cancer on patients and their families in Argentina, and its influence on radiotherapy compliance. Results from a cross-sectional study. Gynecol Oncol. 2007;105(2):335-40.

61. Mekonnen H, Medhin G, Tomlinson M, Alem A, Prince M, Hanlon C. Impact of maternal common mental disorders on child educational outcomes at 7 and 9 years: a population-based cohort study in Ethiopia. BMJ Open. 2018:8:e018916. https://doi.org/10.1136/bmjopen-2017-018916.

62. Tirfessa K, Lund C, Medhin G, Hailemichael Y, Fekadu A, Hanlon C. Food insecurity among people with severe mental disorder in a rural Ethiopian setting: a comparative, population-based study. Epidemiol Psychiatr Sci. 2017. https://doi.org/10.1017/s2045796017000701.

63. Hoque ME, Dasgupta SK, Naznin E, Al Mamun A. Household coping strategies for delivery and related healthcare cost: findings from rural Bangladesh. Trop Med Int Health. 2015;20(10):1368-75.

64. Quintussi M, Van de Poel E, Panda P, Rutten F. Economic consequences of ill-health for households in northern rural India. BMC Health Serv Res. 2015;15:179.

65. Nielsen RB, Garasky S, Chatterjee S. Food insecurity and out-of-pocket medical expenditures: competing basic needs? Fam Consum Sci Res J. 2010;39(2):137-51.

66. Bernard DM, Johansson P, Zhengyi F. Out-of-pocket healthcare expenditure burdens among non-elderly adults with hypertension. Am J Manag Care. 2014;20:406-16.

67. Grande D, Barg FK, Johnson S, Cannuscio CC. Life disruptions for midlife and older adults with high out-of-pocket health expenditures. Ann Fam Med. 2013;11(1):37-42.

68. Hailemichael Y, Hanlon C, Tirfessa K, Docrat S, Alem A, Medhin G, Lund C, Chisholm D, Fekadu A, Haile Mariam D. Mental health problems and socioeconomic disadvantage: a controlled household study in rural Ethiopia. Int J Equity Health. 2018; under review.

69. Bogale T, Haile Mariam D, Ali A. Costs of illness and coping strategies in a coffee-growing rural district of Ethiopia. J Health Popul Nutr. 2005;23(2):192-9.

70. Mahal A, Karan A, Engelgu M. The economic implication of non-communicable disease for India. Health, Nutrition and Population (HNP) discussion paper. Washington, DC: World Bank; 2004. https://openknowledge. worldbank.org/handle/10986/13649. Accessed 20 Mar 2018.

71. Suramya SJ, Veena SG. Rising prices and coping strategies of urban families in India. Int J Consum Stud. 2006;30(1):55-63.

72. Giles J, Yoo K. Precautionary behavior, migrant networks and household consumption decisions: an empirical analysis using household panel data from rural China. Rev Econ Stat. 2007:89(3):534-51.

73. Haile Mariam D. Traditional insurance mechanisms and the choice of health care providers in Ethiopia. University of California International and Area Studies (UCIAS). 2003;5(2):39. 
74. Gresenz CR, Sturm R. New dimensions of economic well-being among people with mental illness: evidence from Healthcare for Communities. Health Serv Res. 2000;35(5):32-42.

75. Trani J-F, Bakhshi P, Kuhlberg J, Narayanan SS, Venkataraman N, Mishra NN, Groce NE, Jadhav S, Deshpande S. Mental illness, poverty and stigma in India: a case-control study. BMJ Open. 2015;5:e06355. https://doi. org/10.1136/bmjopen-2014-006355.

76. World Health Organization. A guide to identifying the economic consequences of disease and injury. Geneva: World Health Organization; 2009.
77. Federal Democratic Republic of Ethiopia. Ministry of Health. Ethiopia's Fifth National Health Accounts. 2010/2011. Addis Ababa. Ethiopia. 2014 http://apps.who.int/nha/database/DocumentationCentre/Index/en. Accessed 15 Feb 2018.

\section{Publisher's Note}

Springer Nature remains neutral with regard to jurisdictional claims in published maps and institutional affiliations.
Ready to submit your research? Choose BMC and benefit from:

- fast, convenient online submission

- thorough peer review by experienced researchers in your field

- rapid publication on acceptance

- support for research data, including large and complex data types

- gold Open Access which fosters wider collaboration and increased citations

- maximum visibility for your research: over $100 \mathrm{M}$ website views per year

At BMC, research is always in progress.

Learn more biomedcentral.com/submissions 